\title{
REVIEW OF ROAD SAFETY THEORIES AND MODELS
}

\section{PRZEGLĄD TEORII MODELI BEZPIECZEŃSTWA RUCHU DROGOWEGO}

\author{
Kazimierz Jamroz \\ Department of Highway Engineering, Faculty of Civil Engineering and Environment, \\ Gdansk University of Technology, ul. Narutowicza 11, 90-952 Gdansk, Polska \\ Katedra Inżynierii Drogowej, Wydział Inżynierii Lądowej i Środowiska, \\ Politechnika Gdańska, ul. Narutowicza 11, 90-952 Gdańsk, Polska \\ kjamroz@pg.gda.pl
}

\begin{abstract}
It has been 100 years since the first attempts at trying to explain why road accidents happen. There have been a number of theories and models studying this and road safety has become a field of scientific study.

The paper will present how the theories and models of road safety developed and how they are used for road safety management. Four groups of the most advanced theories are distinguished: static theories, causal theories, system and behavioral theories. This division of the theories is followed in the models used for road safety analyses and studies.
\end{abstract}

Key words: road safety, theories, models

Streszczenie. Minęło już 100 lat, kiedy podjęto pierwsze próby badań zmierzające do wyjaśnienia różnych aspektów powstawania wypadków drogowych. W tym okresie narodziło się wiele teorii i modeli wyjaśniających aspekty powstawania wypadków drogowych. W artykule będzie przedstawiony rozwój teorii i modeli stosowanych $\mathrm{w}$ badaniach bezpieczeństwa ruchu drogowego oraz wykorzystywanych $\mathrm{W}$ zarządzaniu bezpieczeństwem ruchu drogowego. Wyróżniono cztery grupy najbardziej rozwiniętych teorii: teorie statystyczne, teorie przyczynowe, teorie systemowe $\mathrm{i}$ teorie behawioralne. Według tak podzielonych teorii sklasyfikowano modele stosowane $\mathrm{w}$ badaniach $\mathrm{i}$ analizach bezpieczeństwa ruchu drogowego.

Slowa kluczowe: bezpieczeństwo ruchu drogowego, teorie, modele. 


\section{REVIEW OF ROAD SAFETY THEORIES AND MODELS}

\section{Introduction}

Road safety has been studied, analysed and improved for more than a hundred years. This work has produced a number of theories and accident models, including models of road accidents. It is safe to say that road safety is a full-fledged scientific field of study comprising a number of elements which can be arranged in the shape of a pyramid (base sciences, related disciplines, theories, models and experiments). The scientific discipline of road safety draws on the experience of many base sciences (techniques, medicine, social behaviour) and many scientific disciplines (mathematics, physics, road traffic engineering, highway engineering, safety, transport, education, psychology, sociology, ergonomics, medicine, law, urban planning). All this makes it an interdisciplinary field [7]. The cognitive pillars of today's science are made up by the last three layers of the pyramid, i.e. the triad: theory - experiment - model. The development and relations between these layers are important factors of cognition [8]. This paper gives an overview of the theories and models used in road safety research. The following are the definitions of theory and model in the field of road safety. Theory is a systematically organised knowledge explaining a specific field of reality which can be applied in a broad scope of possibilities (circumstances) and based on a system of assumptions, accepted laws and principles of analysis, forecasting or explaining nature or a specific behaviour of a set of phenomena. With this definition of theory in road safety we can further distinguish four basic types of theories: stochastic, causal, systemic and behavioural.

Models are made to idealise or simplify reality. The very nature and degree of the simplification depend on the knowledge, needs and information held by the researcher and may change depending on the objective of the study. The common feature of theory and model is that they relate to reality in a simplified and abstract way.

In arguing the case for theories and models it is important to say that rules, principles and procedures are not systematically organised or given or commonly available to those studying road accidents. 


\section{Review of road traffic theories}

It has been a hundred years since the first attempts at explaining the different aspects of how road accidents happen. Within this time there have been many theories explaining why accidents happen. There are four periods of the history of road accident research. These are given in Figure 1 [1]. Each of these periods was dominated by one of four groups of road accident theories: stochastic, causal, systemic and behavioural.

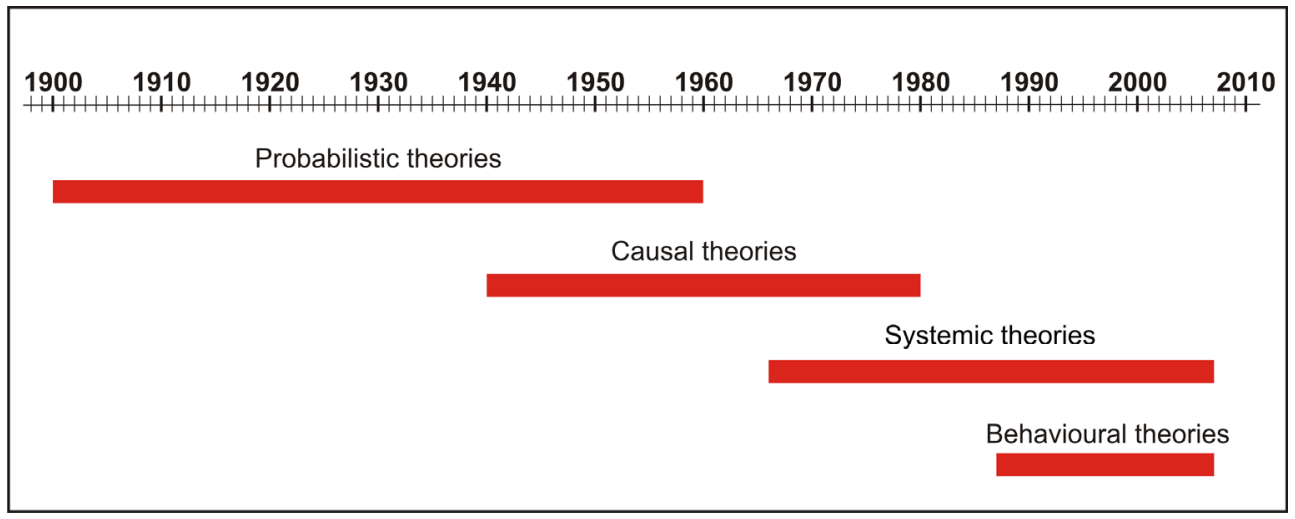

Fig. 1 Chronologic sequence of groups of road safety theories [1]

\subsection{Stochastic theories}

Stochastic theories dominated road accident analyses in the first half of the previous century. Within this period road accidents are analysed as random events and from the point of statistical accident theories. The precursor of the random events theory is Brotkiewicz, who discovered that the distribution of killed in a year is almost perfectly random and the Poisson model gives a good description of the random process. Bortkiewicz's results helped to accept the idea that accidents are purely random and that man has no control over them [1]. Further work by other researchers shifted from the opinion that accidents are accidental to claiming that they are caused by people suffering from personal disorders. The second model that takes into account the abnormal concentration of accidents in some road users was the negative binomial model, which is still used today to describe the distribution of road accidents.

The use of other stochastic models to describe road safety in detail such as regression, time series, stochastic processes, spatial, econometric, etc. 
models finally led to the conclusion that while the majority of road accidents are caused by ordinary drivers there are many other factors that are not related to the driver [1].

So far the most common road safety models were regression models. Because the data describing independent variables are easily available, these road accident models are fairly accurate [2]. Econometric models are playing an ever increasing role. Unfortunately stochastic theories and models are not enough to describe a road accident and suggest relevant road safety measures.

\subsection{Causal theories}

Causal theories of accidents claimed that only an exact knowledge of the real factors causing accidents can help to prevent them. We can distinguish two main trends in causal accident theories: deterministic (sequence of events) and probabilistic (set of factors). Heinrich is considered the precursor of the theory based on the sequence of events [6]. He developed the "domino theory" which is based on the assumption that an accident consists of a single event with a cause. Consequently, better safety, according to this theory, requires that the cause of the accident is established and eliminated. The most developed theories are those of multi-linear event sequences, which assume that accidents are an element of a series of events and suggest a process approach to accidents [13].

Human factors are a major research problem. Many of the studies since the 1960s suggested a strong contribution of the human factors in causing accidents. It is estimated that as much as $60 \%$ of accidents in industry, $70-80 \%$ of accidents in aviation and $85-95 \%$ of road accidents are connected with human factors. There are two approaches to analysing human factors: causal and systemic. Errors are a natural element of human behaviour but they cost too much. But the factors causing errors are numerous. In categorising errors we define those that occur during trained behaviour (errors as unintentional activities) and those that occur during untrained behaviour or in problem solving (performance errors) [14]. The most frequent factors include environmental factors, personal features (e.g. gender, age, practice and training), factors that modify driver behaviour (alcohol, drugs, weather), vehicle equipment, supervised behaviour and many others. The effect of human factors on road accidents can be reduced by making driving more or less automatic.

When analysing the causes of road accidents, an ever increasing use is made of factor, lateral chain of events (trees), sequential or network models, 
although not as often as in other branches of transport. By using causal theories, and primarily sequential, network and tree models (events, errors or decisions), we can run analyses of a number of causes of road accidents. If identified, they can be eliminated or their impact reduced.

There have been a number of studies on the influence of the human factor on traffic user behaviour and road safety. Four main types of driver behaviour have been identified, which directly lead to accidents: distraction, carelessness and misperception, drowsiness and risky, competitive and aggressive behaviour. But still there are many types of problems caused by new vehicles and new elements of transport infrastructure and how these affect road user behaviour and safety that must be studied. As an example, the dynamic space of visibility, drugs used by road users, telematic devices, etc. are among the new areas requiring research. The causal approach to analysing accidents was based on the assumption that the real causes of accidents can only be identified by detailed studies of each accident and the events leading up to the accident. This approach is probably based on microbiology and identifies the causes of diseases by studying the microorganisms that transfer infections and other mechanisms causing sickness.

\subsection{Systemic theories}

With a growing number of cars in the 1940s and 1950s in the USA, the number of accidents went up which showed that accidents can be caused by anyone, not just by extremely clumsy people. There are reasons to believe that the causal theory of accidents cannot explain accidents entirely. With a strong focus on the causal theory of accidents and human error, the 1950s saw a misaligned road safety policy aiming to change human behaviour only. It quickly became clear how ineffective it is. It also became evident that claiming that people make mistakes is not enough to prevent accidents. What must be known is why people cause accidents. This assumption led to the development of a new theory of accidents, the so called systemic theory.

The main assumption of the systemic theory was that accidents result from failure to adjust when the components of the safety system interact. According to the theory none of the elements can be considered more important than the others. People make mistakes, but why? The answer offered by the systemic theory is: mistakes are made because the system has the wrong design and does not match human abilities. Consequently, this theory combines information from individual accidents and creates an area 
of knowledge on the system and its stability, because the individual layers (levels) of the system increase the risk of an accident [15].

The most frequently used models in the area of safety include the models of control, convergence, deviations and management derived from the general theory and the models of hidden conditions, pathological models, "carrier protection", flow of energy and energy improvements coming from epidemiological and energy theories.

The high reliability systems theory says that many accidents of dangerous technologies could be avoided through prevention such as good quality design, construction and system management [9].

The theory of systems applied to road transport is designed primarily to eliminate accidents by modifying the technical elements of the transport system. The systemic theory is so far the best. The improvements in the roads system, traffic enforcement and vehicle design have significantly reduced accident rates and casualties in western motorised countries [1].

Systemic theories and models are used to identify the relations and dependencies that have an effect on accidents (so called factors transferred in time and space) and factors that occur at the time and place of the road accident to build a system of road safety measures, monitoring and control of the dependencies and relations. An example of this approach is a preventative programme known as the Haddon matrix who is considered the precursor of the multi-disciplinary approach to road safety and credited with building the basis for systemic studies [4], [5].

\subsection{Behavioural theories}

The last 15-20 years have shown that not even the systems theory can explain accidents. Could it be that accidents are an unsolvable problem? A new approach was put forward by in 1980 by Gerlad Wilde giving the basis for behavioural theories.

The basic assumption of all behavioural theories is how people assess risk and accept it as a very important determining factor of accidents. Similarly to the previous theories, there are several groups of theories here as well: homeostasis of risk, behavioural adjustment and change of health behaviour. Homeostasis is the body's ability to maintain a constant interior environment which is possible thanks to adjustment mechanisms based on feedback irrespective of external factors. Wilde formulated a simple thesis which is that the only factor that causes sustainable changes in accident numbers long-term is when the public as a whole wants safety. He found that every community only has as many accidents as it wants to have and the 
only way to change this is by changing the desired risk level (desired level of safety) [17]. Wilde's model has triggered a serious international debate and finally it was agreed that the homeostasis of risk cannot be invalidated. Wilde however did not say how best to measure the "assumed level of risk" and how to change it. As a result, the theory becomes a "black box" which does not accept any measurements.

However, it must be said that the theory of the homeostasis of risk takes account of all road users (motorised and non-motorised.) Many scientists agree that Wilde has identified important mechanisms in his theory when he said that safety measures do not yield the expected results on all roads. There is no doubt that road safety relies on the successes of road safety programmes. The more the public want to prevent accidents, the greater the acceptance of more stringent road safety measures [1].

Wilde's attempt at formulating a general theory of accidents has failed. The theory of behavioural adjustment is more limited. It assumes that road users adjust their behaviour to risk factors and road safety measures to a greater or smaller extent, but not to compensate entirely for risk factors which cause behavioural adjustment [12].

Work on the theory of heath changes began only recently. The theory explains the effects of pro-health behaviour of individuals and the public on casualty reduction. It stems from environmental theories. According to it the number of casualties or the likelihood of becoming a casualty in an accident depends on the following elements: health promotion (education, motorisation, communication with the public, programmes, policy, legal regulations, organisational changes), human factors (local level, social level) and behaviours and the environment. The theory helps to explain which behaviours and environmental factors are responsible for increasing the number of casualties and suggest safety measures [3]. Road accidents and casualties are an important element affecting public health, which makes this theory worthwhile.

\subsection{Other theories and models}

Road traffic deserves special attention of science. This is because of the high frequency of risk and the resulting severe social loss. This comes as a consequence of a significant exposure to risk of road users and the relatively high likelihood of incidents, conflicts, collisions or road accidents. In short: the risk components are substantial in this case. [16]: This is why work is under way to apply other theories to road safety. These include the analogies of the theory of reliability in modelling accidents, models of the theory of 
disasters for anticipating road incidents in conditions of high congestion or the theory of alertness used in the military and the theory of distraction applied in studying workplace accidents.

The theories and accident models proposed so far have not produced a general model, one that could be used to formulate conclusions on all aspects of deduction. The theories and models presented in this paper show that road safety is a complex phenomenon and one that needs insight into a number of fields of study. This is why to ensure a better description of road accidents we need to combine several accident models in order to solve safety problems. For the purpose of accident analysis, there are four groups of models: MORT [13], KIK [10], STAMP [11] and the meta model [1].

\section{Use of theories in road transport safety}

When formulating road safety measures, scientific support is frequently asked for. A number of theories are used which are mainly causal, epidemiologic, systemic and behavioural theories.

Causal theories and sequential models are used to analyse recognisable causes of accidents and the relations are determined between the number and effects of accidents and a set of important factors (social, economic, road, traffic and others). The objective is to avoid or limit the most significant causes and circumstances of road accidents.

Epidemiologic theories and models are used to analyse the "carriers" and hidden relations that affect the consequences of accidents. The objective is to build protective barriers and identify public health indicators. As an example, a safety measures programme known as the Haddon matrix, who gave the foundations for a multi-disciplinary approach to road safety and systemic research.

Systemic theories and models are used to identify all dependencies and relations that have an effect on accidents (so called factors transferred in time and space) and factors that occur at the time and place of a road accident in order to build a system of safety measures and a system for monitoring and control of the dependencies and relations.

Behavioural theories and models are used to establish the effects of behaviour of individuals on accidents and the ability to convince the public and politicians about the need for programmes and evaluating their effectiveness. 


\section{Conclusion}

The theories presented in this paper show that road safety is a complex phenomenon and one that needs insight into a number of fields of science. The theories proposed so far have not produced a general theory, one that could be used as a basis for identifying all causes of accidents. Each of the proposed theories has some truth in it. It is true that accidents are in a way accidental. It is also true that some people are involved in accidents more often than others. It is common knowledge that to err is human and that some errors can cause accidents. It is also true that we are trying to adjust the technical measures to human abilities and limitations to reduce accidents. However, there is no one system able to protect us completely from accidents. This is because the human drive to push the borders and experience the thrill of driving cannot be eliminated altogether.

The literature covers in detail three theories developed by Heinrich, Haddon and Wilde, which have made a major contribution to safety research including road safety.

The recent behavioural theories are focussing on risk analysis as used in engineering and traffic safety management to best meet the current needs of risk assessment prior to infrastructure projects.

None of the theories presented ensures a complete and scientific explanation of the phenomenon of road accidents. Each theory only covers a specific part or explains the problem partially. To help with that combined models are used (meta models) to describe accidents, identify the barriers and preventative measures and to introduce a system of monitoring and control. Considering the shortcomings of the existing theories and models, including road accident models, and the changing conditions (new technologies, different types of accidents, new types of risk, increasingly complicated systems and organisations), there is a real need to continue and develop research on new theories and more perfect models of road safety. The recommended direction for science would be to adapt the existing theories and safety models used in other fields of study including those applied in the safety of air, water and rail transport and the development of meta models.

\section{References}

[1]. Elvik R., Vaa T.: The Handbook of Road Safety Measures. Elsevier 2004. 
[2]. Gaca S.: Badania prędkości pojazdów i jej wpływu na bezpieczeństwo ruchu drogowego. Zeszyty Naukowe Politechniki Krakowskiej, Inżynieria Lądowa nr 75, Kraków 2002.

[3]. Gielen G.C., Sleet D.: Application of Behavior-change theories and Methods to Injury Prevention. Epidemiology Revenue 2003;25:65-76.

[4]. Haddon W. A logical framework for categorizing highway safety phenomena and activity. Journal of Trauma 1972;12:193-207.

[5]. Haddon W. Options for the prevention of motor vehicle crash injury. Israel Journal of Medicine Science 1980;16:45-68.

[6]. Heinrich H.W.: Industrial Accident Prevention: A Scientific Approach. 1950

[7]. Jamroz K.: Teorie i modele stosowane $w$ badaniach i działaniach prewencyjnych na rzecz bezpieczeństwa ruchu drogowego. Konferencja Krynica 2006.

[8]. Kleiber M., Modelowanie i Symulacja Komputerowa . Moda czy Naturalny Trend Rozwoju Nauki, Nauka, No 4, 1999, pp 29 . 41.

[9]. Kosmowski K.: Metodyka analizy ryzyka w zarządzaniu niezawodnością i bezpieczeństwem elektrowni jądrowych. Politechnika Gdańska, Monografie 33, Gdańsk 2003.

[10]. Kowalewski S.: Model badania wypadków. Atest 200, nr 5.

[11]. Leveson N.G.: Model-Based Analysis of Socio-Technical Risk. Massachusetts University of Technology, ESD-WP-2004-08

[12]. Naatanen R., Summala H.: Zachowanie użytkowników dróg a wypadki drogowe. PWN Warszawa 1985.

[13]. Pietrzak L.: Badanie wypadków przy pracy - modele i metody. Centralny Instytut Ochrony Pracy - Państwowy Instytut Badawczy, Warszawa 2004

[14]. Rasmussen J.: Proactive Risk Management in Dynamic Society: Karlstad: Swedish Rescue Services Agency 2000

[15]. Surry , J., Industrial Accident Research , University of Toronto , Toronto, Canada, 1969

[16]. Szymanek A: Bezpieczeństwo i ryzyko w technice. Politechnika Radomska, Radom 2006

[17]. Wilde G.J.S.: Target Risk. Dealing with the danger of death, disease and damage in everyday decisions. Queen's University, Komgston, Ontario Canada, 1994 


\section{PRZEGLĄD TEORII MODELI STOSOWANYCH W BEZPIECZEŃSTWIE RUCHU DROGOWEGO}

\section{Wstęp}

W ponad stuletniej historii badań, analiz i prowadzenia działań prewencyjnych na rzecz bezpieczeństwa wypracowano wiele teorii i modeli wypadków, w tym także modeli wypadków drogowych. Można przyjąć, że bezpieczeństwo ruchu drogowego wyrosło już na dyscypliną naukową, składającą się wielu elementów, które można uszeregować w formie piramidy (nauki bazowe, dyscypliny pokrewne, teorie, modele i eksperymenty). Dyscyplina naukowa bezpieczeństwo ruchu drogowego korzysta $\mathrm{z}$ doświadczeń wielu nauk bazowych (techniki, medycyna, zachowania społeczne) oraz wielu dyscyplin naukowych (matematyki, fizyki, inżynierii ruchu drogowego, inżynierii drogowej, bezpieczeństwa, transportu, edukacji, psychologii, socjologii, ergonomii, medycyny, prawa, urbanistyki). Czyli jest dziedziną prowadzącą badania interdyscyplinarne [7]. Natomiast filarami poznawczymi dzisiejszej nauki, są trzy ostanie warstwy tej piramidy, czyli triada: teoria - eksperyment - model. Zatem rozwój i relacje między tymi warstwami są istotnymi czynnikami poznania rzeczywistości [8]. W niniejszej pracy przedstawiono przegląd teorii i modeli stosowanych $\mathrm{w}$ badaniach bezpieczeństwa ruchu drogowego. Przyjęto poniższe definicje odnośnie teorii i modelu $\mathrm{w}$ bezpieczeństwie ruchu drogowego.

Teoria jest to systematycznie uporządkowana wiedza wyjaśniająca daną dziedzinę rzeczywistości, dająca się zastosować w szerokim zakresie możliwości (okoliczności) oraz, że opiera się na systemie założeń, zaakceptowanych praw i zasad dotyczących analizy, prognozowania lub inaczej wyjaśniania natury lub specyficznego zachowania zbioru zjawisk. Przyjmując taką definicje teorii w bezpieczeństwie ruchu drogowego można wyodrębnić cztery podstawowe grupy teorii: stochastyczne, przyczynowe, systemowe, behawioralne.

Model jest z założenia pewną idealizacją lub uproszczeniem rzeczywistości. Sam charakter i stopień uproszczenia zależy od wiedzy, potrzeb i wiadomości badacza i może się zmieniać w zależności od celu badań. Wspólną właściwością dla teorii i modelu jest odnoszenie się do rzeczywistości w formie uproszczonej i abstrakcyjnej. Najbardziej 
przekonującym argumentem za odkrywaniem teorii i modeli jest założenie, że reguły, zasady i procedury nie są nigdzie systematycznie zorganizowane i podane ani nie są powszechnie dostępne dla badającego wypadek drogowy.

\section{Przegląd teorii w bezpieczeństwie ruchu drogowego}

Minęło już 100 lat, kiedy podjęto pierwsze próby badań zmierzające do wyjaśnienia różnych aspektów powstawania wypadków drogowych. W tym okresie narodziło się wiele teorii wyjaśniających aspekty powstawania wypadków drogowych. W badaniach wypadków ruchu drogowego można wyróżnić cztery okresy, które przedstawiono na rys.1 [1]. W każdym $\mathrm{z}$ tych okresów dominowała jedna $\mathrm{z}$ czterech grupy teorii powstawania wypadków drogowych: stochastyczne, przyczynowe, systemowe, behawioralne.

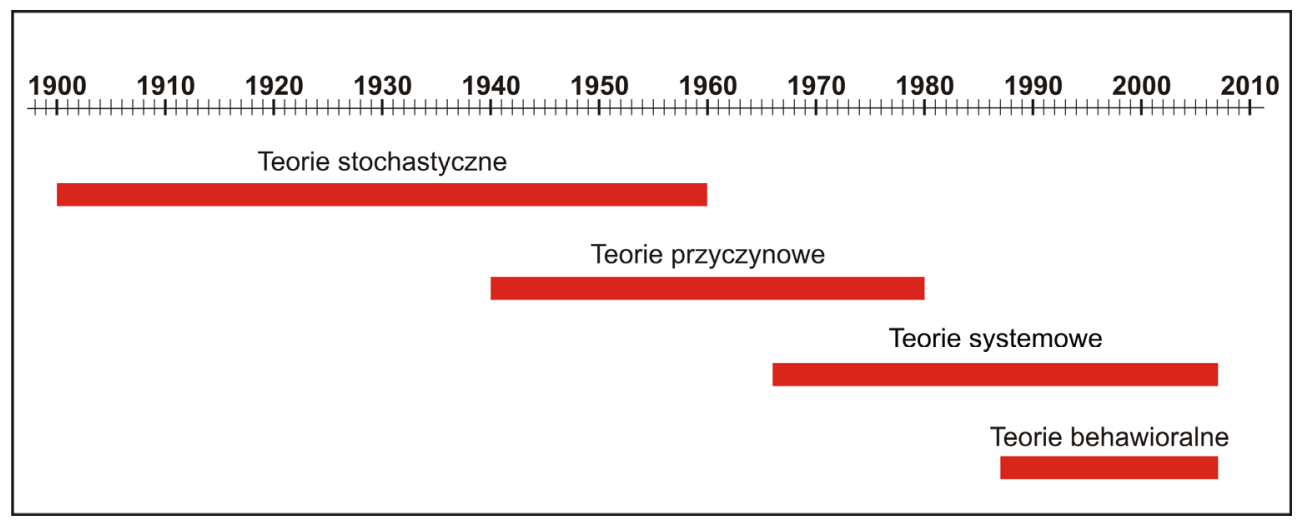

Rys.1 Chronologiczne następstwo grup teorii bezpieczeństwa ruchu drogowego [1]

\subsection{Teorie stochastyczne}

Teorie stochastyczne dominowały w analizach wypadków drogowych przez pierwszą połowę poprzedniego wieku. W tym okresie wyróżniono okres analiz wypadków jako zdarzeń losowych i okres statystycznych teorii wypadków. Jako prekursora tej teorii wypadków jako zdarzeń losowych uznaje się Brotkiewicza, który odkrył, że rozkład liczby ofiar śmiertelnych $\mathrm{w}$ ciagu roku jest prawie doskonale losowy, a model Poissona bardzo dobrze 
opisuje ten proces losowy. Rezultaty Bortkiewicza doprowadziły do akceptacji idei, że wypadki są czysto losowe a człowiek nie ma nad nimi żadnej kontroli [1]. Dalsze prace innych badaczy spowodowały, ze analizy przesunęły się od poglądu, że wypadki są kwestią przypadku poprzez stwierdzenie, że są one winą osób mających jakieś osobiste zaburzenia. Drugim stosowanym modelem, uwzględniającym nienormalną koncentrację wypadków u niektórych uczestników ruchu był model dwumianowy ujemny, który stosowany jest do opisu rozkładów wypadków drogowych do dzisiaj.

Zastosowanie innych modeli stochastycznych do szczegółowego opisu zjawiska bezpieczeństwa ruchu drogowego jak modele: regresyjne, szeregów czasowych, procesów stochastycznych, przestrzenne, ekonometryczne itp. pozwoliło na sprecyzowanie w końcowym okresie stwierdzenia, że większość wypadków drogowych jest powodowana przez zwykłych kierowców, ale do ich powstania przyczynia się wiele czynników nie tylko związanych z kierowcą [1].

Dotychczas najczęściej stosowanymi modelami w bezpieczeństwie ruchu drogowego były modele regresyjne, które ze względu na dużą dostępność danych opisujących zmienne niezależne, umożliwiają uzyskiwanie poprawnych modeli wypadków drogowych [2]. Coraz większą rolę odgrywają także modele ekonometryczne. Niestety teorie i modele stochastyczne nie są wystarczające do opisu wypadku drogowego i określania na tej podstawie działań usprawniających bezpieczeństwo ruchu drogowego.

\subsection{Teorie przyczynowe}

Przyczynowe teorie wypadków dowodziły, że tylko przy dokładnym poznaniu prawdziwych czynników powodujących wypadki, możliwe jest im zapobieganie. Można wyróżnić dwa nurty w występujące w przyczynowych teoriach wypadków: deterministyczny (następstwo zdarzeń) i probabilistyczny (zbiór czynników). Jako prekursora teorii wykorzystującej następstwo zdarzeń uznaje się Heinricha [6] z opracowaną przez niego „teorią domina”, która bazuje na założeniu, że wypadek składa się $\mathrm{z}$ pojedynczego zdarzenia, które ma przyczynę. Zatem poprawa bezpieczeństwa według tej teorii polega na znalezieniu i wyeliminowaniu przyczyny wypadku. Najdalej rozwinięte są natomiast teorie sekwencji zdarzeń wieloliniowych, które zakładają, że wypadki są elementem ciagu zdarzeń i proponują procesowe spojrzenie na zjawisko wypadku [13]. 
Czynniki ludzkie stanowią nadal duży problem badawczy. Wiele badań prowadzonych od lat 60 - tych ubiegłego wieku wykazywało na dość duży udział czynników ludzkich w powstawaniu wypadków. Szacuje się, że ok. $60 \%$ wypadków w przemyśle, $70-80 \%$ wypadków w lotnictwie i $85-95 \%$ wypadków drogowych związanych jest z czynnikami ludzkimi. Istnieją dwa podejścia do analizy wpływu czynników ludzkich; przyczynowe i systemowe. Błędy są naturalnym elementem zachowań człowieka, ale kosztują zbyt wiele. Ale czynniki wpływające na ich powstawanie mogą być różne. Kategoryzacja błędu wyróżnia błędy pojawiające się podczas wyuczonych zachowań (pomyłki jako działania niezamierzone) i takie, które pojawiają się podczas zachowań nie wyuczonych lub rozwiązywania problemów (błędy wykonania) [14]. Do najczęściej wymienianych czynników należą czynniki środowiskowe, cechy osób (np. płeć, wiek, praktyka i trening), czynniki modyfikujące zachowania kierowców (alkohol, narkotyki, pogoda), wyposażenie pojazdu, nadzór nad zachowaniem i wiele innych. Zmniejszenie wpływu czynników ludzkich na powstawanie wypadków związane jest $\mathrm{z}$ automatyzacja lub częściową automatyzacją czynności wykonywanych przez człowieka jako kierowcę.

Coraz częściej, chociaż nie tak często jak w innych dziedzinach transportu, do analizy przyczyn wypadków drogowych stosowane są modele czynnikowe, bocznego łańcucha zdarzeń (drzewa), sekwencyjne lub sieciowe. Korzystając zatem z teorii przyczynowych, a przede wszystkim modeli sekwencyjnych, sieciowych i drzew (zdarzeń, błędów lub decyzji) możliwe jest prowadzenie analiz wielu przyczyn wypadków drogowych, których rozpoznanie umożliwi wyeliminowanie lub ograniczenie wpływu najbardziej istotnych przyczyn i okoliczności wypadków drogowych.

Mimo, że przeprowadzono już wiele badań dotyczących wpływu czynnika ludzkiego na zachowania uczestników ruchu i bezpieczeństwo ruchu. Zidentyfikowano miedzy cztery główne rodzaje zachowań kierowców, które prowadza bezpośrednio do wypadków: odwrócenie uwagi, nieostrożność i błędne spostrzeganie, senność oraz zachowania ryzykowne, rywalizacyjne i agresywne. To nadal jeszcze wiele problemów związanych z wpływem nowych pojazdów i nowych elementów infrastruktury transportowej na zachowania uczestników ruchu i bezpieczeństwo wymaga badań. Przykładowym problemem jest dynamiczna przestrzeń widoczności, stosowanie narkotyków przez uczestników ruchu, zastosowanie urządzeń telematyki itp. Podejście przyczynowe do analizy wypadków opierało się na założeniu, że prawdziwe powody wypadków mogą być poznane tylko dzięki szczegółowym studiom nad każdym wypadkiem, warunkami otaczającymi 
oraz zdarzeniami, które do niego doprowadziły. Takie podejście jest prawdopodobnie oparte na mikrobiologii i jej poszukiwaniach przyczyn chorób poprzez identyfikację mikroorganizmów przenoszących infekcje oraz inne mechanizmy powodujących choroby.

\subsection{Teorie systemowe}

Wzrost parku samochodowego w latach 40-tych i 50-tych w USA i towarzyszący mu wzrost ilości wypadków, pokazał, że wypadki może powodować każdy a nie tylko wyjątkowo niezręczni ludzie. Dało się wyczuć, że teoria przyczynowa wypadków nie może całkowicie wyjaśniać występowania wypadków. Duże skupienie uwagi w przyczynowej teorii wypadków i na błędach ludzkich doprowadziło w latach 50-tych do niewłaściwego kierunku poprawy bezpieczeństwa jedynie poprzez zmianę zachowania ludzi. Szybko stało się jasne, że takie próby jedynie w małym stopniu były skuteczne. Również szybko zrozumiano, że twierdzenie iż człowiek jest omylny to za mało by przeciwdziałać wypadkom. Trzeba było dowiedzieć się, dlaczego ludzie powodują wypadki. Realizacja tego założenia doprowadziła do powstania nowej teorii wypadków tj. teorii systemowej.

Podstawowym założeniem teorii systemowej było, że wypadki są rezultatem nieprzystosowania $\mathrm{w}$ interakcji pomiędzy elementami składowymi całego systemu bezpieczeństwa. Zgodnie z tą teorią, nie można wskazywać jednego elementu systemu jako ważniejszego niż inne. Ludzie popełniają błędy, ale dlaczego to robią? Odpowiedź zaproponowana przez teorię systemów brzmiała: błędy są popełniane, ponieważ system nie jest prawidłowo zaprojektowany i nie jest dostosowany do ludzkich możliwości. Zatem teoria ta pozwala na łączenie informacji z pojedynczych wypadków celem stworzenia obszaru wiedzy o działaniu danego systemu i jego stabilności, gdyż poszczególne warstwy (poziomy) systemu przyczyniają się do narastania ryzyka wypadku [15].

Najczęściej stosowanymi w bezpieczeństwie modelami są modele: kontroli, zbieżności, odchyleń i zarządzania wywodzące się z teorii generalnej oraz modele: ukrytych warunków, patologiczne, ,nosiciel - ochrona”, przepływu energii i usprawnień energetycznych wywodzące się $\mathrm{z}$ teorii epidemiologicznych i energetycznych.

Teoria systemów wysokiej niezawodności mówi, że wielu wypadków w niebezpiecznych technologiach można uniknąć poprzez działania prewencyjne takie jak wysoki poziom projektowania, budowy i zarządzania systemem [9]. 
Teoria systemów w odniesieniu do transportu drogowego dotyczy przede wszystkim wyeliminowania wypadków poprzez modyfikacje technicznych elementów systemu transportowego. Teoria systemowa jest najlepszą $\mathrm{z}$ dotychczasowych. Wprowadzone udoskonalenia w systemie dróg, kontroli ruchu i projektowaniu pojazdów znacznie zredukowały wskaźniki koncentracji wypadków i ich ofiar na drogach w zachodnich zmotoryzowanych krajach [1].

Korzystając $\mathrm{z}$ teorii i modeli systemowych poszukuje się wszystkich zależności i relacji mających wpływ na doprowadzenie do wypadku (tzw. czynniki przeniesione $\mathrm{w}$ czasie i przestrzeni) oraz czynników działających na miejscu i czasie wypadku drogowego w celu budowy systemu działań prewencyjnych oraz systemu monitorowania i kontroli funkcjonowania poszczególnych zależności i relacji. Przykładem tego podejścia jest program działań prewencyjnych znany pod nazwą macierzy Haddona, który jest uważany za prekursora wielodyscyplinarnego podejścia do zagadnienia bezpieczeństwa ruchu drogowego oraz stworzenia podstaw do późniejszych badań systemowych [4], [5].

\subsection{Teorie behawioralne}

Ostatnie 15-20 lat dowiodło, że nawet teoria systemów nie w pełni wyjaśnia zjawisko występowania wypadków. Być może problem wypadków jest nierozwiązywalny? Nowe podejście zasugerował w roku 1980 Gerlad Wilde dając podstawy dla teorii behawioralnych.

Podstawowym założeniem wszystkich teorii behawioralnych jest ocena ryzyka przez ludzi i jego akceptacja jako bardzo ważnej determinanty wypadków. Podobnie jak w poprzednich, tak i w tej grupie rozróżniamy kilka teorii: homeostazy ryzyka, przystosowania behawioralnego, zmiany zachowań zdrowotnych.

Homeostaza jest to zdolność organizmu do utrzymania stałości środowiska wewnętrznego, która jest możliwa dzięki mechanizmom dostosowawczym działającym na zasadzie sprzężenia zwrotnego, niezależnie od działania czynników zewnętrznych. Wilde postawił w prosty sposób tezę, że jedynym czynnikiem powodującym trwałe zmiany w ilości wypadków w długim okresie czasu jest pragnienie bezpieczeństwa przez całą społeczność. Stwierdził, że każda społeczność posiada taką ilość wypadków, jaką chce mieć i jedynym sposobem by obniżyć tę liczbę jest zmiana docelowego poziomu ryzyka (pożądany poziom bezpieczeństwa) [17]. Model Wilde'a sprowokował poważną międzynarodową dyskusję w wyniku, której zgodzono się, że nie można obalić teorii homeostazy ryzyka. Jednakże 
Wilde nie określił jak najlepiej pomierzyć „założony poziom ryzyka” i jak wpłynąć by go zmienić. Teoria ta staje się więc „czarną skrzynką”, do której żadna miara nie może być włożona.

Nie mniej jednak należy zaznaczyć, że teoria homeostazy ryzyka uwzględnia wszystkich uczestników ruchu drogowego (zmotoryzowanych i niezmotoryzowanych.)

Wielu naukowców zgadza się, że Wilde zidentyfikował ważne mechanizmy w swojej teorii stwierdzając, że nie na wszystkich drogach środki bezpieczeństwa dają zamierzone efekty. Nie ma wątpliwości, że najsilniejszym oczekiwaniem względem bezpieczeństwa ruchu drogowego są sukcesy programów przeciwdziałania powstawaniu wypadków. Im większe pragnienie społeczne by przeciwdziałać wypadkom tym mocniejsze środki poprawy bezpieczeństwa są akceptowane [1].

Próba Wilda by sformułować generalną teorię wyjaśniającą wypadki nie powiodła się. Bardziej ograniczoną teorią jest teoria przystosowania behawioralnego. Teoria zakłada, że użytkownicy drogi dostosowują swoje zachowanie do czynników ryzyka i środków bezpieczeństwa ruchu w większym lub mniejszym zakresie, ale nie koniecznie w taki sposób, by całkowicie rekompensować czynniki ryzyka, które powoduja behawioralne przystosowanie [12].

Prace nad teorią zmian zdrowotnych rozpoczęto niedawno. Teoria wyjaśnia wpływ zachowań pro zdrowotnych osób indywidualnych i społeczeństwa na zmniejszenie liczby ofiar. Wywodzi się ona z teorii ekologicznych. Według tej teorii liczba ofiar lub prawdopodobieństwo bycia ofiarą wypadku zależy od następujących elementów: promocji zdrowia (edukacja, komunikacja społeczna, programy, polityka, regulacje prawne, zmiany organizacyjne), czynników ludzkich (poziom lokalny, poziom społeczny) oraz zachowań i otoczenia. Teoria ta pozwala wyjaśnić, które zachowania i czynniki środowiskowe są odpowiedzialne za zwiększanie liczby ofiar oraz wskazać metody działań prewencyjnych [3]. Wypadki drogowe i ich ofiary są istotnym elementem wpływającym na poziom zdrowia publicznego, dlatego zasadne jest zwrócenie uwagi na tą teorię.

\subsection{Inne teorie i modele}

Ruch drogowy zasługuje na szczególną uwagę badaczy. Wynika to z faktu, że niebezpieczne zdarzenia drogowe pojawiają się często i prowadzą do dużych strat społecznych. A jest to efektem znacznej ekspozycji zagrożenia uczestników ruchu oraz relatywnie dużego prawdopodobieństwa zdarzeń typu: incydent, konflikt, kolizja lub wypadek drogowy. Mówiąc 
krócej: składowe ryzyka są tutaj duże. [16]: Dlatego trwają poszukiwania możliwości zastosowania innych teorii $\mathrm{w}$ bezpieczeństwie ruchu drogowego. Są to między innymi wykorzystanie analogii teorii niezawodności $\mathrm{w}$ modelowaniu procesu powstawania wypadków drogowych, modeli teorii katastrof do przewidywania incydentów drogowych generowanych w warunkach dużego zatłoczenia, czy też: teorii czujności stosowanej w wojsku i teorię roztargnienia stosowanej w badaniach wypadków przy pracy.

Dotychczas zaproponowane teorie i modele wypadków nie zaowocowały takim generalnym modelem, który mogłaby służyć do formułowania wniosków dotyczących wszystkich aspektów wnioskowania. Przedstawione w niniejszym opracowaniu teorie i modele pokazują, że bezpieczeństwo ruchu drogowego jest mocno złożonym zjawiskiem i potrzebującym wglądu w wiele dyscyplin naukowych. Dlatego dla lepszego opisu zjawisk wypadków drogowych konieczne jest poszukiwanie połączenia kilku modeli wypadków dla rozwiązywania problemów bezpieczeństwa. W analizach wypadków znane są cztery grupy takich modeli: model MORT [13], model KIK [10], model STAMP [11] i meta model [1].

\section{Wykorzystanie teorii w bezpieczeństwie transportu drogowego}

W formułowaniu działań prewencyjnych na rzecz bezpieczeństwa ruchu drogowego coraz częściej sięga się po wsparcie naukowe. Korzysta się przy tym $\mathrm{z}$ wielu teorii, a przede wszystkim z elementów teorii przyczynowych, epidemiologicznych, systemowych i behawioralnych.

Korzystając $\mathrm{z}$ teorii przyczynowych i modeli sekwencyjnych prowadzi się analizę rozpoznawalnych przyczyn wypadków drogowych i określa się zależności liczby i konsekwencji wypadków od zbioru istotnych czynników (społecznych, ekonomicznych, drogowych, ruchowych i innych) w celu unikania lub ograniczenia najbardziej istotnych przyczyn i okoliczności wypadków drogowych.

Korzystając z teorii i modeli epidemiologicznych prowadzi się analizę „nosicieli” i ukrytych zależności wpływających na konsekwencje wypadków w celu stworzenia barier ochronnych i określenia wskaźników modelu zdrowia publicznego. Przykładem tego podejścia jest program działań prewencyjnych znany pod nazwą macierzy Haddona, który postawił podwaliny do wielodyscyplinarnego podejścia do zagadnienia bezpieczeństwa ruchu drogowego oraz stworzenia podstaw do późniejszych badań systemowych. 
Korzystając $\mathrm{z}$ teorii i modeli systemowych poszukuje się wszystkich zależności i relacji mających wpływ na doprowadzenie do wypadku (tzw. czynniki przeniesione w czasie i przestrzeni) oraz czynników działających na miejscu i czasie wypadku drogowego w celu budowy systemu działań prewencyjnych oraz systemu monitorowania i kontroli funkcjonowania poszczególnych zależności i relacji.

Korzystając $\mathrm{z}$ teorii i modeli behawioralnych poszukuje się wyjaśnień wpływu zachowań poszczególnych ludzi na powstawanie wypadków oraz możliwości przekonywania społeczeństwa i polityków o konieczności wprowadzenia działań programowych i oceny ich efektywności .

\section{Podsumowanie}

Przedstawione w niniejszym opracowaniu teorie pokazuja, że bezpieczeństwo ruchu drogowego jest mocno złożonym zjawiskiem i potrzebującym wglądu w wiele dyscyplin naukowych. Dotychczas zaproponowane teorie wypadków nie zaowocowały taką generalną teorią, która mogłaby służyć jako podstawa do określania wszystkich przyczyn wypadków. Każda z proponowanych teorii ma w sobie ziarno prawdy. Prawdą jest, że wypadki są $\mathrm{w}$ pewnym sensie elementem przypadku. Prawda jest również, że są ludzie, którzy biorą udział w wypadkach częściej niż inni. Powszechnie wiadomo, że mylić się jest rzeczą ludzką i niektóre z błędów mogą być przyczyną wypadków. Prawdą jest także, że staramy się dostosować środki techniczne do możliwości i ograniczeń ludzkich, co powoduje zmniejszenie liczby wypadków. Jakkolwiek żaden system nie jest w stanie całkowicie zabezpieczyć nas przed wypadkami. Gdyż ludzkiego pragnienia do przekraczania granic i doświadczania dreszczu emocji w ruchu drogowym nie uda się całkowicie wyeliminować.

Bardzo dużo uwagi w literaturze poświęcono trzem teoriom stworzonym przez: Heinricha, Haddona i Wilde’a, które wniosły bardzo duży wkład w rozwój badań nad bezpieczeństwem, w tym także nad bezpieczeństwem ruchu drogowego oraz prowadzenia działań prewencyjnych.

Ostatnio rozwijane teorie behawioralne nakierowane na analizę ryzyka wykorzystywaną $\mathrm{w}$ inżynierii i zarządzaniu bezpieczeństwem ruchu wychodzą najbardziej naprzeciw aktualnym potrzebom przeprowadzenia ocen ryzyka przed podejmowaniem decyzji inwestycyjnych i modernizacyjnych.

Żadna $\mathrm{z}$ przedstawionych teorii nie daje całkowitego, naukowego wyjaśnienia fenomenu wypadku drogowego. Każda teoria reprezentuje 
pewien wycinek lub daje tylko częściowe wyjaśnienie tego zjawiska. W tym stanie rzeczy pewna protezą jest stosowanie modeli łączonych (meta modeli) do opisu zjawiska wypadku, zidentyfikowania barier i środków zaradczych oraz wprowadzenia systemu działań monitorujących i kontrolnych.

Biorąc pod uwagę niedoskonałości istniejących teorii i modeli wypadków, w tym także wypadków drogowych, oraz zmieniające się ciągle uwarunkowania (zmiany technologii, zmiany natury wypadków, nowe rodzaje zagrożeń, coraz większe skomplikowanie systemów i organizacji) konieczne jest kontynuowanie i rozwijanie prac badawczych zmierzających do tworzenia nowych teorii i budowy bardziej doskonałych modeli bezpieczeństwa ruchu drogowego. Zalecanym kierunkiem prowadzenia badań $\mathrm{w}$ tym zakresie powinno być zaadaptowanie istniejących teorii i modeli bezpieczeństwa stosowanych $w$ innych dziedzinach nauki, w tym także stosowanych $\mathrm{w}$ bezpieczeństwie transportu lotniczego, wodnego i kolejowego, a także rozwój meta modeli.

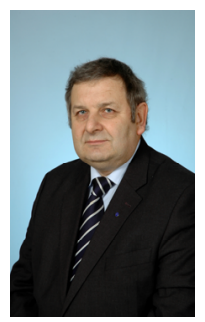

Phd Eng. Kazimierz Jamroz, Gdańsk University of Technology, Highway Engineering Departament, speciality: traffic engineering, road safety, intelligent transport systems 